\title{
THE DISTRIBUTION OF THE TERRESTRIAL ISOPOD HYLONISCUS ADONIS (VERHOEFF, 1927) (ISOPODA: ONISCIDEA) IN CROATIA
}

\section{Ivan Antonović ${ }^{1}$, Andreja Brigić ${ }^{2}$, Jana BedeK ${ }^{3}$ \& Zorana Sedlar $^{4}$}

\author{
${ }^{1}$ Slavka Kolara 45, HR-10 410 Velika Gorica \\ ${ }^{2}$ Division of Zoology, Department of Biology, Faculty of Science, Rooseveltov trg 6, \\ HR-10 000 Zagreb (andreja.brigic@biol.pmf.hr) \\ ${ }^{3}$ Croatian Biospeleological Society, Demetrova 1, HR-10 000 Zagreb \\ ${ }^{4}$ Division of Botany, Department of Biology, Faculty of Science, Marulićev trg 20/II, \\ HR-10 000 Zagreb
}

\begin{abstract}
Antonović, I., Brigić, A., Bedek, J. \& Sedlar, Z.: The distribution of terrestrial isopod Hyloniscus adonis (Verhoeff, 1927) (Isopoda: Oniscidea) in Croatia. Nat. Croat., Vol. 24, No. 1, 139-149, 2015, Zagreb.

This paper presents the distribution of the terrestrial isopod Hyloniscus adonis (Verhoeff, 1927) in Croatia. It was recorded for the first time at the edge of Dubravica peat bog and the adjacent forest. Additionally, it was collected at the edges of Đon močvar peat bog. Revision of the terrestrial isopod collection of the Croatian Biospeleological Society revealed that this species also occurs in central and eastern part of Croatia. Our results reveal that $H$. adonis is a hygrophilic species inhabiting various types of forests in the colline and montane belts. It prefers humid soils with thick litter and humus layers and most probably seldom leaves its shelter. H. adonis is extremely rare in open bog habitats, most likely due to the harsh environmental conditions (e.g. high soil humidity, low $\mathrm{pH}$ values) and can be considered as a tyrphoxenous species. Additionally, it was also found in the entrance zones of caves, most likely due to the favourable microclimatic conditions. It seems to be a temporary cave dweller and can be classified as a trogloxenous species.
\end{abstract}

Key words: peat bog, Dubravica, Đon močvar, cave, tyrphoxenous species, trogloxenous species

Antonović, I., Brigić, A., Bedek, J. \& Sedlar, Z.: Rasprostranjenost kopnenog jednakonošca Hyloniscus adonis (Verhoeff, 1927) (Isopoda: Oniscidea) u Hrvatskoj. Nat. Croat., Vol. 24, No. 1, 139-149, 2015, Zagreb.

U radu je prikazana rasprostranjenost vrste Hyloniscus adonis (Verhoeff, 1927) u Hrvatskoj. Ova vrsta je prvi puta zabilježena na cretu Dubravica i okolnoj šumi. Zabilježena je također i na rubnom staništu creta Đon močvar. Redeterminacija zbirke kopnenih jednakonožaca Hrvatskog biospeleološkog društva pokazala je da ova vrsta dolazi i na nekolicini drugih lokaliteta u središnjoj i istočnoj Hrvatskoj. Rezultati pokazuju da je $H$. adonis higrofilna vrsta koja nastanjuje različite tipove šuma brežuljkastog i brdskog pojasa. Preferira vlažna tla s gustim slojem listinca i humusa, te rijetko napušta svoje skrovište. Vrlo je rijetka vrsta na otvorenim cretnim staništima, najvjerojatnije zbog ekstremnih okolišnih prilika (npr. visoke vlažnosti tla, niskih $\mathrm{pH}$ vrijednosti) te se smatra tirfoksenom vrstom. Nadalje, ova vrsta je pronađena i u ulaznim zonama špilja, najvjerojatnije zbog povoljnih mikroklimatskih prilika. Najvjerojatnije je povremeni stanovnik špilja i može biti klasificirana kao trogloksena vrsta.

Ključne riječi: cret, Dubravica, Đon močvar, špilja, tirfoksena vrsta, trogloksena vrsta

\section{INTRODUCTION}

Terrestrial isopods (Isopoda Latreille, 1817; Oniscidea Latreille, 1802) are one of the main groups of soil macrofauna widely distributed in the Palaearctic region. However, 
the terrestrial isopod fauna of Croatia is poorly explored and most of the data are from the first half of the $20^{\text {th }}$ century (e.g. Csiki, 1926; KARAman, 1966; РотоčNiK, 1989). Recently, only karst areas have been systematically explored and new terrestrial isopod species have been described (BedeK \& TAiti, 2009; KARAman et al., 2009; BedeK et al., 2011). Additionally, some papers dealing with isopod diversity in various habitats have recently been published (FARKAS \& KrČMAR, 2004; FARKAS \& Vilisics, 2008; AnTONOvić et al., 2012). In Croatia 131 species have been recorded to date (BEDEK et al., 2011; Antonović et al., 2012).

The genus Hyloniscus Verhoeff, 1908 includes 26 species, distributed through the central and eastern parts of Europe. In Croatia, two species of the genus have been previously recorded (VerhoefF, 1930; Farkas \& KrČmar, 2004; Farkas \& Vilisics, 2008). H. dalmaticus Verhoeff, 1930 is a range-restricted endemic species, distributed in the vicinity of Split (Dalmatia) (VerhoefF, 1930), while H. riparius (C. Koch, 1838) is widely distributed across Central and Eastern Europe (Schmalfuss, 2003). It was reported for Croatia in Ротос̌мıк (1989); however, the cited literature data actually refer to the Slovenian part of Istria: Krain-Istrien (Wëchtler, 1937; Strouhal, 1939, Schmalfuss, 2003). It was recently found in the Baranja region (FARKAs \& KRČMAR, 2004) and in floodplain forests and river banks along the Drava River (FARKAS \& VIlisics, 2008).

H. adonis was originally described by Verhoeff (1927) from Planina village in the Municipality of Postojna in Slovenia. It is distributed in Austria (Strounal, 1948, 1951), Bosnia and Herzegovina (Buturović, 1955), north-east Italy (Argano et al., 1995) and Slovenia (VerhoefF, 1927; Strouhal, 1951). H. adonis was first recorded in Croatia in the Dubravica bog, Hrvatsko zagorje region (Antonović et al., 2012). This species obviously prefers habitats with higher soil humidity and a thick layer of humus and leaves (Verhoeff, 1927; Méhel丷̈, 1929; Strouhal, 1964; Antonović et al., 2012). However, data on the distribution and ecology of $H$. adonis are rather scarce, due to the lack of terrestrial isopod specialists and the shortage of faunistic surveys. Therefore, the objectives of this study were: (1) to revise the genus Hyloniscus from terrestrial isopod collections in Croatia; (2) to present the current distribution of H. adonis in Croatia and (3) to give further information on the ecology and habitat preferences of this species.

\section{MATERIAL \& METHODS}

\section{Study area}

The study was conducted at two acidophilous peat bogs: Dubravica bog (Fig. 1a) and Đon močvar bog (Fig. 1b) and their adjacent forest habitats (Tab. 1). Terrestrial isopods were collected also during cave and soil fauna inventories in Medvednica Nature Park (seven different localities evenly distributed on the mountain; 21 sites in total) (Fig. 1c), Papuk Nature Park (32 caves and springs and 10 sites for soil fauna), the Banija region (Pecka cave) and in the area of the Donja Dobra River (57 caves and springs) (Fig. 1d) (Tab. 1).

\section{Sampling and identification}

Several sampling methods were used in order to collect terrestrial isopods, e.g. pitfall traps, hand collecting, soil extraction using a Berlese funnel and a Winkler/Moczarski eclector. 

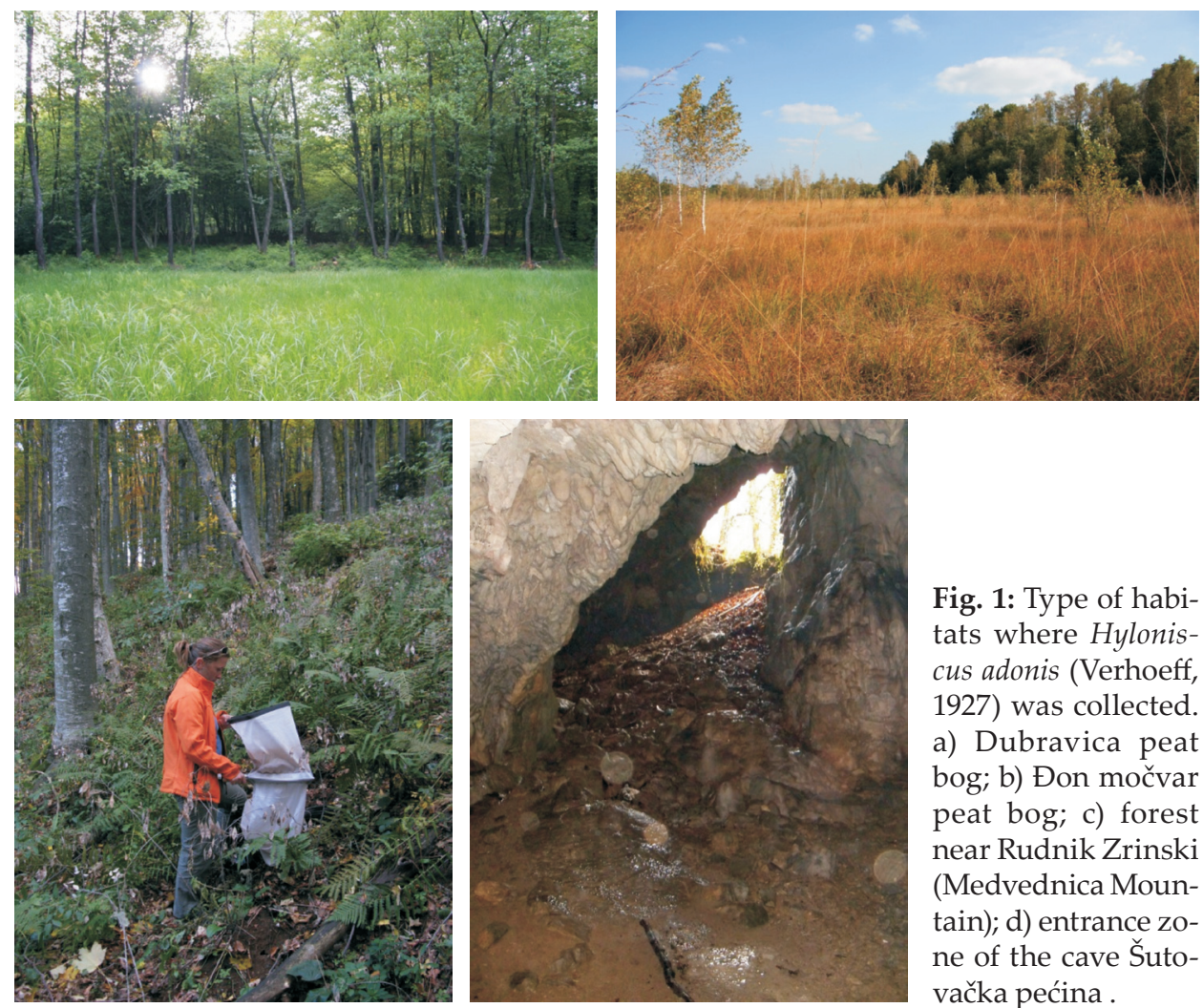

Fig. 1: Type of habitats where Hyloniscus adonis (Verhoeff, 1927) was collected. a) Dubravica peat bog; b) Đon močvar peat bog; c) forest near Rudnik Zrinski (Medvednica Mountain); d) entrance zone of the cave Šutovačka pećina .

Pitfall traps were used in order to collect soil arthropods in the peat bogs. Five pitfall traps of $0.3 \mathrm{dm}^{3}$ volume were used per site and 15 sites were sampled in total (three sites in Dubravica bog and 12 in Đon močvar bog). The traps were partially filled with saturated salt solution with a drop of neutrally-smelling detergent in order to reduce the surface tension of the liquid. A Styrofoam roof was placed above each trap to protect it from litter and rain. The trapping period covered the whole vegetation season of two years (2008-2009), from the end of April to the beginning of December at both the studied areas. Additional samplings were conducted during 2010 in Đon močvar bog. Pitfall traps were emptied once a month. However, when pitfall trapping is used, less active species and species associated with specific habitat types may not be recorded (ANONYMous, 1998). Therefore, terrestrial isopods were also collected by hand using tweezers at each site (in both bogs studied) for a 15 minute period in May and June 2012.

A soil fauna inventory on Mt Medvednica was conducted from April to November 2008. Specimens were extracted from soil using Berlese funnels $(25 \mathrm{~cm}$ in diameter, $27 \mathrm{~cm}$ height, with $2 \mathrm{~mm}$ mesh screens and holes $5 \mathrm{~mm}$ in diameter at the edges of the mesh screens, without a lamp; they were placed in flasks containing $96 \%$ ethanol for five days) and a Winkler/Moczarski eclector (4-6 mm coarse-mesh bags, a collection bottle containing $96 \%$ ethanol, left to dry at room temperature for seven days). 
Tab. 1. Description of sampling sites where Hyloniscus adonis (Verhoeff, 1927) specimens were sampled. Legend: IA - Ivan Antonović collection, ITC (CBS) - the Isopoda Terrestria Collection (Croatian Biospeleological Society).

\begin{tabular}{|c|c|c|c|c|c|c|}
\hline Location & Site & Coordinates & $\begin{array}{c}\text { Altitude } \\
(\mathrm{m})\end{array}$ & $\begin{array}{c}\text { Cave } \\
\text { length/ } \\
\text { depth }(\mathrm{m})\end{array}$ & Plant association & Collection \\
\hline \multirow[b]{2}{*}{$\begin{array}{l}\text { Hrvatsko } \\
\text { zagorje }\end{array}$} & \multirow{2}{*}{$\begin{array}{l}\text { Dubravica } \\
\text { bog }\end{array}$} & N $45^{\circ} 57^{\prime} 51.48^{\prime \prime}$ & \multirow[b]{2}{*}{160} & \multirow[b]{2}{*}{-} & bog: Rhynchosporetum albae W. Koch 1926 & \multirow[b]{2}{*}{ IA } \\
\hline & & E $15^{\circ} 45^{\prime} 15.48^{\prime \prime}$ & & & $\begin{array}{l}\text { forest: Epimedio-Carpinetum betuli } \\
\text { (Ht.1938) Borh. } 1963\end{array}$ & \\
\hline \multirow{10}{*}{$\begin{array}{l}\text { Medved- } \\
\text { nica } \\
\text { Mountain }\end{array}$} & \multirow{2}{*}{$\begin{array}{l}\text { Rudnik } \\
\text { Zrinski }\end{array}$} & $\mathrm{N} 45^{\circ} 53^{\prime} 14.1^{\prime \prime}$ & \multirow{2}{*}{790} & \multirow[b]{2}{*}{-} & \multirow{2}{*}{$\begin{array}{l}\text { Lamio orvalae-Fagetum (Ht. 1938) Borh. } \\
1963\end{array}$} & \multirow[b]{2}{*}{ ITC (CBS) } \\
\hline & & E $15^{\circ} 55^{\prime} 51.1^{\prime \prime}$ & & & & \\
\hline & \multirow{2}{*}{ Glavica } & N $45^{\circ} 50^{\prime} 50.9^{\prime \prime}$ & \multirow[b]{2}{*}{415} & \multirow[b]{2}{*}{-} & \multirow{2}{*}{$\begin{array}{l}\text { Epimedio-Carpinetum betuli (Ht.1938) } \\
\text { Borh. } 1963\end{array}$} & \multirow[b]{2}{*}{ ITC (CBS) } \\
\hline & & E $15^{\circ} 52^{\prime} 54.5^{\prime \prime}$ & & & & \\
\hline & \multirow{2}{*}{ Ponikve } & $\mathrm{N} 45^{\circ} 51^{\prime} 23.7^{\prime \prime}$ & \multirow{2}{*}{490} & \multirow{2}{*}{-} & \multirow{2}{*}{$\begin{array}{l}\text { Epimedio-Carpinetum betuli (Ht.1938) } \\
\text { Borh. } 1963\end{array}$} & \multirow{2}{*}{ ITC (CBS) } \\
\hline & & E $15^{\circ} 52^{\prime} 56.0^{\prime \prime}$ & & & & \\
\hline & \multirow{2}{*}{ Veternica } & $\mathrm{N} 45^{\circ} 50^{\prime} 29.1^{\prime \prime}$ & \multirow{2}{*}{350} & \multirow{2}{*}{$7128 /-$} & \multirow{2}{*}{$\begin{array}{l}\text { Epimedio-Carpinetum betuli (Ht.1938) } \\
\text { Borh. } 1963\end{array}$} & \multirow{2}{*}{ ITC (CBS) } \\
\hline & & E $15^{\circ} 52^{\prime} 43.3^{\prime \prime}$ & & & & \\
\hline & \multirow{2}{*}{ Sljeme } & $\mathrm{N} 45^{\circ} 54^{\prime} 05.6^{\prime \prime}$ & \multirow{2}{*}{980} & \multirow{2}{*}{-} & \multirow{2}{*}{$\begin{array}{l}\text { Festuco drymeiae-Abietetum Vukelić et } \\
\text { Baričević } 2007\end{array}$} & \multirow[b]{2}{*}{ ITC (CBS) } \\
\hline & & E $15^{\circ} 57^{\prime} 47.0^{\prime \prime}$ & & & & \\
\hline \multirow{4}{*}{$\begin{array}{l}\text { Papuk } \\
\text { Mountain }\end{array}$} & & $\mathrm{N} 45^{\circ} 30^{\prime} 16.6^{\prime \prime}$ & & & Galio odorati-Fagetum sylvaticae Sougnez & \\
\hline & Suhodol & E $17^{\circ} 42^{\prime} 14.2^{\prime \prime}$ & 650 & - & et Thill 1959 & ITC (CBS) \\
\hline & Lijepa & $\mathrm{N} 45^{\circ} 30^{\prime} 06.7^{\prime \prime}$ & & & Galio odorati-Fagetum sylvaticae Sougnez & \\
\hline & jama & Е $17^{\circ} 42^{\prime} 48.1^{\prime \prime}$ & 725 & $15 / 7$ & et Thill 1959 & ITC (CBS) \\
\hline & Đon & & & & $\begin{array}{l}\text { bog: Drosero-Caricetum echinatae Horvat } \\
\text { (1950) 1962; Rhynchosporetum albae W. } \\
\text { Koch } 1926\end{array}$ & \\
\hline & $\begin{array}{l}\text { močvar } \\
\text { bog }\end{array}$ & $\mathrm{N} 45^{\circ} 19^{\prime} 4.33^{\prime \prime}$ & 130 & - & $\begin{array}{l}\text { edge: Frangulo-Alnetum glutinosae Rauš } \\
1968\end{array}$ & IA \\
\hline Banija & & E $15^{\circ} 54^{\prime} 32.83^{\prime \prime}$ & & & $\begin{array}{l}\text { forest: Epimedio-Carpinetum betuli } \\
\text { (Ht.1938) Borh. } 1963\end{array}$ & \\
\hline & & $\mathrm{N} 45^{\circ} 15^{\prime} 23.9^{\prime \prime}$ & & & & \\
\hline & Pecka & E $15^{\circ} 50^{\prime} 55.5^{\prime \prime}$ & 200 & $6 / 0$ & & ITC (CBS) \\
\hline & Šutovačka & $\mathrm{N} 45^{\circ} 18^{\prime} 50.2^{\prime \prime}$ & 200 & $26 / 15$ & & ITC (CBS) \\
\hline & pećina & E $15^{\circ} 16^{\prime} 26.5^{\prime \prime}$ & & & & \\
\hline Donja & Jama na & $\mathrm{N} 45^{\circ} 20^{\prime} 50.5^{\prime \prime}$ & 275 & & & ITC (CBS) \\
\hline $\begin{array}{l}\text { Dobra } \\
\text { River }\end{array}$ & Bertiji 2 & E $15^{\circ} 15^{\prime} 12.6^{\prime \prime}$ & 275 & known & & $11 \mathrm{C}(\mathrm{CBS})$ \\
\hline & Izvor špilja & $\mathrm{N} 45^{\circ} 19^{\prime} 06.3^{\prime \prime}$ & 170 & & & ITC (CBS) \\
\hline & Trošmarije & E $15^{\circ} 16^{\prime} 38.6^{\prime \prime}$ & $1 / 0$ & known & & $11 \mathrm{C}$ (CDS) \\
\hline
\end{tabular}


The cave fauna inventory on Mt Papuk was conducted from 2004 to 2010, at Donja Dobra River from June 2008 to December 2009 and in the Banija region during March 2009. Terrestrial fauna at these sites was collected by hand using tweezers.

Specimens of $H$. adonis were identified using the original description of VerHoefF (1927) and the identification key of SchmöLzer (1965). Identifications were based on microscopic slides of specific male identifying features (first and second pleopods, seventh pereiopod, antenna and genital papilla). At each location or in the vicinity we collected at least one male. Due to the impossibility of distinguishing Hyloniscus females, they were associated based on comparisons with overall male morphology. Nomenclature is defined according to Schmalfuss (2003).

Specimens from Dubravica and Đon močvar bogs are deposited in the first author's private collection (Ivan Antonović, Zagreb, Croatia), while other specimens are kept in the Isopoda Terrestria Collection of the Croatian Biospeleological Society (deposited in the Croatian Natural History Museum, Zagreb, Croatia).

\section{Environmental variables}

Soil samples were taken at each site in the peat bogs in order to determine soil humidity and $\mathrm{pH}$ values. Soil humidity was determined using the gravimetric method. $\mathrm{pH}$ values were measured in a 1: 2.5 mixture of soil:water using a WTW pH330i meter. These measurements were made according to ŠKORIć (1982).

During soil and cave fauna inventories the air, soil and cave sediment temperature (ca. $10 \mathrm{~cm}$ deep) and relative air humidity were measured using TESTO Mini Thermometer and Kestrel 3000 Pocket Weather Meter.

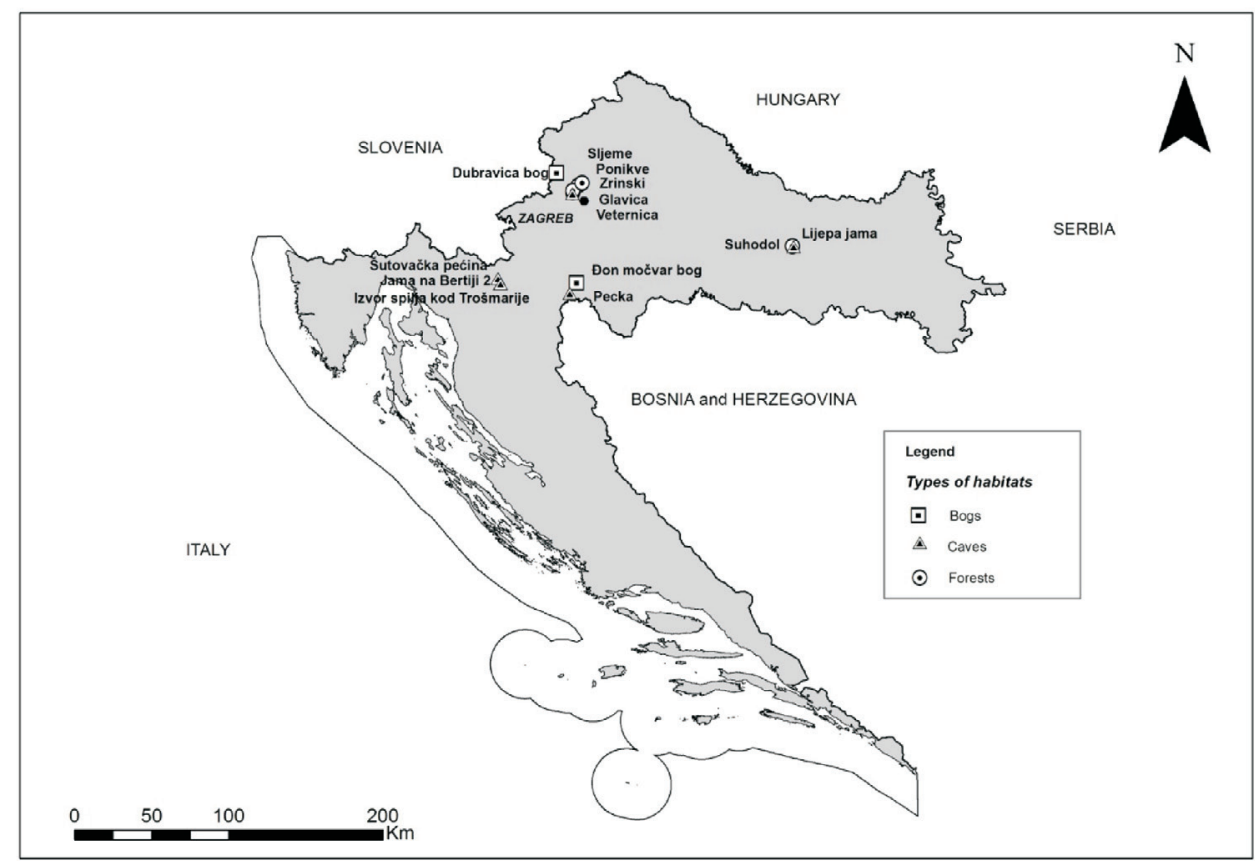

Fig. 2. Distribution of Hyloniscus adonis (Verhoeff, 1927) in Croatia. 


\section{RESULTS AND DISCUSION}

\section{Distribution} 2).

Hyloniscus adonis is distributed in the central and eastern parts of Croatia (Tab. 1, Fig.

It was recorded in Hrvatsko zagorje region, the surroundings of the Donja Dobra River, Medvednica Mountain, the Banija region and Papuk Mountain. Like most other Hyloniscus species, H. adonis has a relatively restricted distribution range (SchmaLfuss, 2003), which is confined to Central Europe and the western part of the Balkan Peninsula.

\section{Ecology and biology}

According to current knowledge, H. adonis (Fig. 3) inhabits peat bogs, in particular their edges and adjacent forest habitats. It occurs in mixed forests dominated by the sessile oak and the common hornbeam (association Epimedio-Carpinetum betuli), but also by montane neutrophilic beech forests and acidic mixed beech and fir forests of Aremonio-Fagion Horvat 1938 alliance (Tab. 1). This species was also found in the entrance zones of several caves (Tab. 2). Regarding altitude, it was found from $130 \mathrm{~m}$ a.s.l. up to $980 \mathrm{~m}$ a.s.l (Tab. 1). In general, it lives in humid and shaded places, in thick layers of leaves and humus. Other authors found this species in a thick layer of litter (VERHOEFF, 1927; MéHEL̈̈, 1929). Furthermore, Strounal (1964) recorded it in beech-maple forest (subassociation Aceri-Fagenion Ellenberg 1963), where the soil is characterised by a thick humus layer and high soil humidity.

Activity density of $H$. adonis was extremely low in the open bog areas (Tab. 2). These habitats are characterised a by thick layer of Sphagnum mosses, high soil humidity (season mean \pm SD: Dubravica bog: centre $-80.44 \% \pm 10.19$; Đon močvar bog: centre $-92.8 \%$ \pm 2.15 ) and low $\mathrm{pH}$ values (Dubravica bog: centre - $4.47 \pm 0.77$; Đon močvar bog: centre - 4.82 \pm 0.58$)$. Although Hyloniscus species are generally highly hygrophylic, it seems that

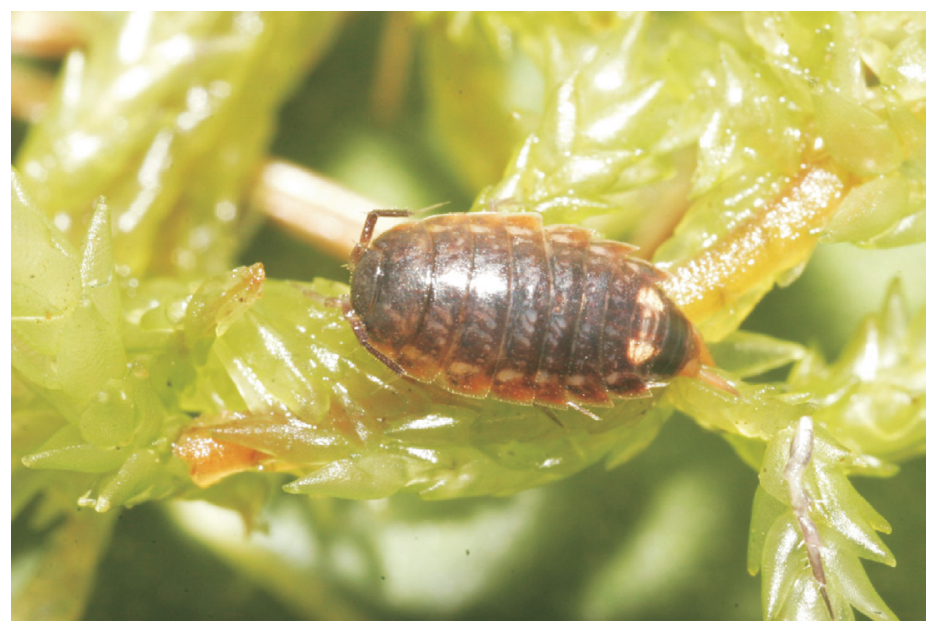

Fig. 3. Hyloniscus adonis (Verhoeff, 1927) collected from the Dubravica peat bog (photo: J. Bedek). 
Tab. 2. Abundance of the terrestrial isopod Hyloniscus adonis (Verhoeff, 1927) at studied sites. Legend: PT - pitfall trapping; HC - hand collecting; BF - Berlese funnel extractions; W/M Winkler/Moczarski eclector; Leg. - legator; AB - Andreja Brigić; AK - Alen Kirin; HCV - Hrvoje Cvitanović; IA - Ivan Antonović; JB - Jana Bedek; ML - Marko Lukić; NM - Nataša Matoš; $\mathrm{RO}$ - Roman Ozimec.

\begin{tabular}{|c|c|c|c|c|c|c|c|c|c|}
\hline Location & Study area & Habitat & Method & 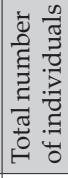 & $\frac{0}{\sum^{\pi}}$ & 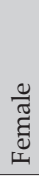 & 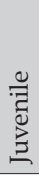 & Leg. & Date \\
\hline \multirow{3}{*}{$\begin{array}{l}\text { Hrvatsko } \\
\text { zagorje }\end{array}$} & \multirow{3}{*}{$\begin{array}{l}\text { Dubravica peat } \\
\text { bog }\end{array}$} & bog & \multirow{3}{*}{ HC \& PT } & 1 & - & 1 & - & \multirow{3}{*}{$\mathrm{AB}$} & VII; 2008. \\
\hline & & edge & & 15 & 8 & 7 & - & & $\begin{array}{l}\text { V, VI, VIII, IX, } \\
\text { X, XI; } 2008 .\end{array}$ \\
\hline & & forest & & 3 & 1 & 2 & - & & VII, XI; 2008 \\
\hline \multirow{4}{*}{ Banija } & \multirow{3}{*}{$\begin{array}{l}\text { Đon močvar } \\
\text { peat bog }\end{array}$} & bog & \multirow{3}{*}{ HC \& PT } & 1 & - & 1 & - & \multirow{3}{*}{ IA } & \multirow{3}{*}{ VI; 2012.} \\
\hline & & edge & & - & - & - & - & & \\
\hline & & forest & & - & - & - & - & & \\
\hline & Pecka & cave entrance zone & $\mathrm{HC}$ & 1 & 1 & - & - & $\mathrm{NM} ; \mathrm{HCV}$ & III; 2009. \\
\hline \multirow{5}{*}{$\begin{array}{l}\text { Mt } \\
\text { Medvednica }\end{array}$} & Rudnik Zrinski & forest & $\mathrm{BF}$ & 1 & 1 & - & - & ML;JB & X; 2008. \\
\hline & Glavica & forest & $\begin{array}{l}\text { BF \& } \\
\text { W-M }\end{array}$ & 3 & - & 1 & 2 & ML;RO & VI; 2008. \\
\hline & Ponikve & forest, spring bank & $\mathrm{BF}$ & 3 & - & - & 3 & ML & VI; 2008. \\
\hline & Veternica & cave entrance zone & W-M & 1 & - & 1 & - & ML;JB & VI; 2008. \\
\hline & Sljeme & forest & W-M & 1 & 1 & - & - & ML;RO & VII; 2008. \\
\hline \multirow{2}{*}{ Mt Papuk } & Suhodol & forest & \multirow{2}{*}{$\mathrm{HC}$} & 1 & - & 1 & - & $\mathrm{RO}$ & X; 2008. \\
\hline & Lijepa jama & cave entrance zone & & 2 & 1 & - & 1 & JB & X; 2008. \\
\hline \multirow{3}{*}{$\begin{array}{l}\text { Donja Dobra } \\
\text { River }\end{array}$} & $\begin{array}{l}\text { Šutovačka } \\
\text { pećina }\end{array}$ & cave entrance zone & \multirow{3}{*}{$\mathrm{HC}$} & 2 & 2 & - & - & $\mathrm{HCV}$;JB & $\begin{array}{c}\text { XII; 2008.; V; } \\
2009 .\end{array}$ \\
\hline & \begin{tabular}{|l|} 
Jama na \\
Bertiji 2 \\
\end{tabular} & cave entrance zone & & 1 & - & 1 & - & JB & V; 2009. \\
\hline & $\begin{array}{l}\text { Izvor špilja kod } \\
\text { Trošmarije }\end{array}$ & cave entrance zone & & 1 & 1 & - & - & AK & V; 2009. \\
\hline
\end{tabular}

H. adonis does not prefer open bog habitats. Most likely this is due to the specific environmental conditions, characterized by high ground water table and low $\mathrm{pH}$ values, factors that limit the spatial distribution of isopods (SutTon, 1972; Wolters \& EкSCHмitT, 1997; Hornung, 2011; Antonović et al., 2012). Also, peat bogs are characterized by a low level of nutrients and presence of Sphagnum sp. mosses which contain polyphenols that are not favourable to isopods (CAMERon \& LAPoint, 1978; Zimmer \& Topp, 1997; Rydin \& JeGLUM, 2006). Interestingly, this species was not recorded in basophilous fens (Jarak and Plaški) where conditions are more suitable (Antonović, unpublished data). There- 
Tab. 3. Measured environmental variables at studied sites.

\begin{tabular}{|c|c|c|c|c|c|c|}
\hline \multicolumn{2}{|l|}{ Location } & Habitat & $\mathrm{t}$ (air) $/{ }^{\circ} \mathrm{C}$ & $\begin{array}{c}\mathrm{t} \text { (cave } \\
\text { sediment } \\
/ \text { oil) } /{ }^{\circ} \mathrm{C}\end{array}$ & $\begin{array}{c}\mathrm{RH} \\
\text { (air) / \% }\end{array}$ & Date \\
\hline \multirow{5}{*}{ Mt Medvednica } & Rudnik Zrinski & forest & 13.7 & 10.1 & 85.3 & X; 2008. \\
\hline & Glavica & forest & - & 17.5 & - & VI; 2008. \\
\hline & Ponikve & forest, spring bank & - & 17.7 & - & VI; 2008. \\
\hline & Veternica & cave entrance zone & - & 12.1 & - & VI; 2008. \\
\hline & Sljeme & forest & - & 13.8 & - & VII; 2009. \\
\hline Mt Papuk & Lijepa jama & cave entrance zone & 10.8 & 9.6 & 100 & X; 2008. \\
\hline \multirow{6}{*}{$\begin{array}{l}\text { Donja Dobra } \\
\text { River }\end{array}$} & \multirow{2}{*}{ Šutovačka pećina } & \multirow{2}{*}{ cave entrance zone } & 8.1 & - & 97.6 & XII; 2008. \\
\hline & & & 9.6 & - & 100 & V; 2009 \\
\hline & \multirow{3}{*}{ Jama na Bertiji 2} & \multirow{3}{*}{ cave entrance zone } & 11.1 & 10.9 & - & V; 2009. \\
\hline & & & 10.6 & - & 100 & V; 2009. \\
\hline & & & 11.0 & - & 100 & XII; 2008. \\
\hline & $\begin{array}{l}\text { Izvor špilja kod } \\
\text { Trošmarije }\end{array}$ & cave entrance zone & 14.0 & - & 96.5 & V; 2009. \\
\hline
\end{tabular}

fore, $H$. adonis could be considered a tyrphoxenous species (vagrants, species that cannot live in bogs) (Peus, 1932; Roubal, 1934). Nevertheless, it seems that $H$. adonis prefers the edges of peat bogs (Tab. 2). The edge of Dubravica bog is covered with strong Rubus sp. plants that have formed a thick root system. The edge area is rich with humus, a litter layer and parts of decaying wood. The area is characterised by high soil humidity (season mean \pm SD: Dubravica bog: edge $-74.47 \% \pm 4.64$ ) and low $\mathrm{pH}$ values (Dubravica bog: edge $-4.1 \pm 0.51$ ). However, oscillations in soil humidity were lower at the edge site than at the bog site which could also affect the spatial distribution of this species (Antonović et al., 2012). Like other terrestrial arthropods, e.g. carabid beetles (BRigić et al., 2009) and some ants (BujAn et al., 2010) it preferred bog edges. The edge area possibly offers more suitable microhabitats and more food sources for terrestrial isopodsothan the bog itself.

$H$. adonis was also found in small caves and the entrance zones of large ones. Most likely these sites are inhabited due to their high humidity levels (locatios mean \pm SD: $85.59 \% \pm 5.38$.) and lower air temperatures (locatios mean \pm SD: $10.02{ }^{\circ} \mathrm{C} \pm 2.11$; Tab. 3 ), both favourable for isopods (Buturović, 1957) (Tab. 3). However, this could also be the result of the speciess natural cryptozoic behaviour in order to find suitable shelters with optimum ecological conditions (Hassall et al., 2005; Hornung, 2011). This species is highly hygrophylic and can survive in caves for shorter or longer periods, but it does not belong among typical cave-dwelling fauna. Therefore, it could be considered a trogloxenous species (a species that uses caves as a shelter but is unable to establish a subterranean population) (SKET, 2008). Since the collection of trogloxenous species was not the main aim of the cave inventories, this could explain the low abundance (Tab. 2) 
and low occurrence of $H$. adonis in cave samples (e.g. one cave out of 32 researched on Mt Papuk; three caves out of 57 researched at the Donja Dobra River area).

Most of the specimens were collected at the side of Dubravica bog while at Đon močvar bog only one female was collected by hand, despite the larger number of pitfall traps. It seems that this species, like the related H. riparius (StrouHal, 1948; FARKAs \& VILISICS, 2008) rarely leaves its shelter. No seasonal activity density could be observed due to the low number of caught specimens that were uniformly collected during the whole season (months: V-4, VI - 3, VII -3, VIII - 3, IX - 2, X-1, XI - 3).

\section{ACKNOWLEDGEMENTS}

The authors would like to thank Stefano Taiti for his help in species identification, Antun Alegro for his help in plant community identifications, Ana Previšić for improving the English, Sanja Gottstein for useful suggestions regarding the manuscript and Marko Lukić, Roman Ozimec, Hrvoje Cvitanović, Nataša Matoš an, Alen Kirin for their help in field sampling. The study was partially supported by Papuk Nature Park, Medvednica Nature Park (project leader Roman Ozimec), Sisak - Moslavina County (project leader Roman Ozimec), Croatian Electricity Company (HEP), and the State Institute for Nature Protection, Republic of Croatia (grant nos. 888/08-1, 888/08-2, 888/083 ). Additionally, the authors would like to thank anonymous reviewers who helped us to improve the manuscript.

Received February 11, 2015

\section{REFERENCES}

Anonymous, 1998: Inventory methods for terrestrial arthropods. Standards for components of British Columbia's biodiversity. Resources Inventory Committee.

Antonović, I., Brigić, A., Sedlar, Z., BedeK, J. \& Šoštarić, R., 2012: Terrestrial isopod community as indicator of succession in a peat bog. In: Śtrus, J., Taiti, S. \& Sfenthourakis, S. (eds.), Advances in Terrestrial Isopod Biology. ZooKeys 176, 171-188.

Argano, R., Ferrara, F., Guglielmo, L., Riggio, S. \& Ruffo, S., 1995: Crustacea Malacostraca II (Tanaidacea, Isopoda, Amphipoda, Euphausiacea). Checklist delle Specie della Fauna Italiana 30. Calderini, Bologna. 52 pp.

Bedek, J. \& Taiti, S., 2009: A new species of Strouhaloniscellus Tabacaru, 1993 (Crustacea: Isopoda: Oniscidea) from a cave in Mt Biokovo, Croatia. Zootaxa 2196, 59-64.

BedeK, J., TAiti, S. \& GotTstein, S., 2011: Catalogue and atlas of cave-dwelling terrestrial isopods (Crustacea: Oniscidea) from Croatia. Natura Croatica 20(2), 237-354.

Brigić, A., Alegro, A., Sedlar, Z., Šegota, V., Šoštarić, R. \& Vujčić-Karlo, S., 2009: Carabid beetles (Coleoptera, Carabidae) in Croatian peat bogs. In: Hengeveld, R., NoordijK, J., Opsteeg, T., Turin, R. \& Vermuelen, H. J. W., (eds.), Carabid beetles as bioindicators, the use of ground beetles in ecological and environmental studies. The usefulness and threats of methods used for monitoring species and populations. Book of abstracts. Willem Beijerinck Biological Station, Westerbork Netherlands. p. 30.

Bujan, J., Brigić, A. \& JešovniK, A., 2010: Ant diversity in Croatian peat bogs. In: NAsh, D. R., Boer, S. P. A., De Fine Licht, H. H. \& Boomsma, J. J., (eds.), Meeting of the International Union for the Study of Social Insects (IUSSI). Book of abstracts. Clausen Offset ApS, Copenhagen. p. 18.

Buturović, A., 1955: Isopodes nouveaux (Isop. terrestria) de Macedoine et Dalmatie. Acta Musei Macedonici Scientiarum Naturalium 3, 145-157.

Buturović, A., 1957: O sistematici, biologiji i biogeografiji trihoniscida Jugoslavije. Godišnjak biološkog inštituta u Sarajevu 1-2, 3-67.

Buturović, A., 1958: Sur la systematique, la biologie et la biogéograhie des Trichoniscidae de la Yougoslavie. Godišnjak biološkog Instituta u Sarajevu 10, 3-67. 
Cameron, G. N. \& La Point, T. W., 1978: Effects of tannins on the decomposition of chinese tallow leaves by terrestrial and aquatic invertebrates. Oecologia 32, 349-366.

CsıKI, E., 1926: Magyarország szárazföldi Isopodái. (Isopoda terrestria Hungariae). Annales historiconaturales Musei nationalis hungarici 23, 1-79.

FARKAS, S. \& KRČMAR, S., 2004: Terrestrial isopods (Isopoda: Oniscidea) of Baranya (Croatia). Natura Croatica 12(2), 161-170.

FARKAs, S. \& Vilisics, F., 2008: Results of the field surveys on terrestrial isopods (Isopoda, Oniscidea) in the Drava basin, Croatia. In: Purger, J. (eds.), Biodiversity studies along the Drava river. University of Pécs, Pécs. p. 143-163.

Hassall, M., Zimmer, M. \& Loureiro, S., 2005: Questions and possible new directions for research into the biology of terrestrial isopods. European Journal of Soil Biology 41, 57-61.

Hornung, E., 2011: Evolutionary adaptation of oniscidean isopods to terrestrial life: structure, physiology and behavior. Terrestrial Arthropod Reviews 4, 95-130.

Karaman, I., Bedek, J. \& Horvatović, M., 2009: Thaumatoniscellus speluncae n. sp. (Isopoda: Oniscidea: Trichoniscidae), a new troglobitic oniscid species from Croatia. Zootaxa 2158, 57-64.

Karaman, M., 1966: Kopneni izopodi (Isopoda terrestria) Jugoslavije. Zbornik filozofskog fakulteta u Prištini 3, 371-404.

MéHel.̈, L. V., 1929: Species generis Hyloniscus. Studia zoologica (Budapest) 1, 1-75.

Peus, F., 1932: Die Tierwelt der Moore unter besonderer Berucksichtigung der europaischen Hochmoore. Handbook Moorkunde (Berlin) 3, 1-277.

Pотос̌Nik, F., 1989: Pregled Favne mokric (Isopoda terrestria) Jugoslavije. Biološki Vestnik 37, 61-82.

Roubal, J., 1934: Die Coleopterenwelt (Tyrphobionte, Tyrphophile, Tyrphoxene, etc.) der Trebonerm (Wittingauer) Moore. Folia Zoologica et Hydrobiologica 7(1), 56-97.

Rydin, H. \& Jeglum, J., 2006: The biology of peatlands. Oxford University Press, New York. 343 pp.

Schmalfuss, H., 2003: World catalog of terrestrial isopods (Isopoda: Oniscidea). Stuttgarter Beiträge zur Naturkunde 654, 1-341.

SснмӧLzer, K., 1965: Bestimmungsbücher zur Bodenfauna Europas. Ordnung Isopoda (Landasseln) 5. Akademie Verlag, Berlin. 468 pp.

Sket, B., 2008: Can we agree on an ecological classification of subterranean animals? Journal of Natural History 42, 1549-1563.

Strouhal, H., 1939: Landasseln aus Balkanhöhlen, gesammelt von Prof. Dr. K. Absolon. 8 Mitteilung: Bulgarien und Altserbien. Bulletin des Institutions royales d'Histoire Naturelle. Sofia 12, 193-205.

Strouhal, H., 1948: Die Landasseln Kärntens und Osttirols. Carinthia (II) 137-138, 103-152.

Strouhal, H., 1951: Die österreichischen Landisopoden, ihre Herkunft und ihre Beziehungen zu den Nachbarländern. Verhandlungen der zoologisch-botanischen Gesellschaft Wien 92, 116-142.

Strouhal, H., 1964: Die österreichischen Haplophthalmus-Arten der mengii-Gruppe (Isop. terr.). Annalen des naturhistorischen Museums in Wien 67, 499-558.

Sutton, S., 1972: Woodlice. Ginn and Company Limited, London. 144 pp.

ŠкоRІс́, A., 1982: Manual for pedological investigations. Faculty of Agriculture, Zagreb. 172 pp.

Verhoeff, K., 1927: Über einige südosteuropäischen Trichonisciden. Zoologischer Anzeiger 70(7/8), 200223.

Verhoeff, K., 1930: Zur Kenntnis osteuropäischer Isopoden. Zoologische Jahrbücher, Abteilung für Systematik, Ökologie und Geographie der Tiere 59, 1-64.

Wächtler, W., 1937: Isopoda (Asseln). In: Brohmer, P., Ehrmann, P. \& Ulmer, G., (eds.), Die Tierwelt Mitteleuropas, vol. 2. Verlag Von Quelle \& Mayer, Leipzig. p. 225-317.

Wolters, V. \& Eкsснмітт, K., 1997: Gastropods, isopods, diplopods and chilopods: neglected groups of decomposer food web. In: BencKISER, G. (eds.), Fauna in soil ecosystems: recycling processes, nutrient fluxes and agriculture production. Marcel Dekker, New York. p. 279-281.

Zimmer, M. \& Topp, W., 1997: Homeostatic responses in the gut of Porcellio scaber (Isopoda: Oniscidea) optimize litter degradation. Journal of Comparative Physiology B167, 582-585. 


\title{
SAŽETAK
}

\section{Rasprostranjenost kopnenog jednakonošca Hyloniscus adonis (Verhoeff, 1927) (Isopoda: Oniscidea) u Hrvatskoj}

\author{
I. Antonović, A. Brigić, J. Bedek \& Z. Sedlar
}

Fauna kopnenih jednakonožaca Hrvatske slabo je istražena i većina podataka potječe iz prve polovice 20. stoljeća (Csiki, 1926; Karaman, 1966; Pljakić, 1970; Ротос̌NiK, 1989). Dosadašnjim radom je ukupno zabilježena 131 vrsta kopnenih jednakonožaca u Hrvatskoj (BedeK et al. 2011.; Antonović et al., 2012).

Vrsta Hyloniscus adonis izvorno je opisana iz sela Planina u općini Postojna, Slovenija (VerhoefF, 1927). Vrsta ima ograničen areal rasprostranjenosti te je do sada utvrđena u Austriji (Strouhal, 1964), Bosni i Hercegovini (Buturović, 1955), Italiji (Argano et al., 1995) i Sloveniji (Verhoeff, 1927; Méhelü, 1929). Prvi puta je zabilježena u Hrvatskoj na cretu Dubravica (Hrvatsko zagorje) i šumi koja okružuje cret, a naknadno je sakupljena i na cretu Đon močvar (Banija) (ANTONović et al., 2012). Redeterminacija zbirke kopnenih jednakonožaca Hrvatskog biospeleološkog društva, pokazala je da ova vrsta dolazi još i na nekolicini drugih lokaliteta na području središnje i istočne Hrvatske.

Na temelju dosadašnjih spoznaja, ova vrsta nastanjuje rubove cretova, različite tipove šumske vegetacije te ulazne zone špilja. Pronađena je na različitim nadmorskim visinama, od 130 m nv do 980 m nv. Preferira vlažna tla, bogata listincem i humusom. Vrlo je rijetka vrsta otvorenih cretnih staništa, što je najvjerojatnije posljedica ekstremnih prilika na takvim staništima (npr. visoke vlage tla i niskog $\mathrm{pH}$ tla). Međutim, u većem broju dolazi na rubovima cretova, što je moguće posljedica većeg broja povoljnih mikrostaništa i izvora hrane, te manje izraženih sezonskih oscilacija u vlazi tla. Zbog svega navedenog ovu vrstu možemo klasificirati kao tirfoksenu vrstu, tj. kao vrstu koja povremeno može doći na otvorenim cretnim staništima, ali koja tamo ne može živjeti.

Vrsta H. adonis je također zabilježena u ulaznim zonama špilja. Ekološka obilježja tih zona je visok udio relativne vlažnosti zraka, niže temperature u odnosu na temperature izvan špilje te velika količina listinca i humusa, što ova staništa čini povoljnim za kopnene jednakonošce (Buturović, 1957; 1958). Kako niti jedna jedinka nije nađena u dubljim dijelovima špilja, možemo zaključiti kako je ovo i trogloksena vrsta koja ulazne zone špilja koristi isključivo kao zaklon. 